\title{
MEASUREMENT OF INTEGRATION TECHNOLOGY IMPLEMENT USING BALANCED SCORECARD APPROACH (CASE STUDY IN AMG)
}

\author{
Verri Kuswanto ${ }^{1}$, Santo F. Wijaya ${ }^{2}$ and Ford Lumban Gaol $^{3}$ \\ ${ }^{1}$ Information System Department, Faculty of Science and Technology, Buddhi \\ Dharma University, Tangerang, Indonesia 15115 \\ ${ }^{2}$ Information Systems Department, School of Information Systems, Bina Nusantara \\ University, Jakarta, Indonesia 11480 \\ ${ }^{3}$ Computer Science Department, School of Computer Science, Bina Nusantara \\ University, Jakarta, Indonesia 11480 \\ ${ }^{1}$ Verri.Kuswanto@buddhidharma.ac.id, ${ }^{2}$ santofw@binus.ac.id, ${ }^{3}$ fgaol@binus.edu.
}

\begin{abstract}
The organization obtains information from a system in its implementation. Attempts to improve system performance and organizational performance are done using the Integration Technology. more efficient and effective operational work with support of Integration Technology in management decisions and satisfaction of information usage, based on measurement of 4 main perspectives in Balanced Scorecard hence there is added value in work system that considered result of implementation of Integration Technology. This study aims to see the value added business work system in the application system application in the company with a case study.
\end{abstract}

Keywords - Value-added, Integration Technology, Measurement, Balanced Scorecard

\section{INTRODUCTION}

The application system has many developments in achieving process efficiency in the industry as the basis of technological progress. Manager Integration is a development that made to support process business teamwork with the functional of the company's growing systems. Integration Technology is a entry data tools into information in the Company System. Integration Technology with a matrix that provides added value in the performance of enterprise applications to support enterprise systems achieve more competitive and planned planning, plotting an emphasis on improving the overall business of the company. Integration Technology implementation in enterprise system applications, in some perspectives greatly add value in the company's work processes. to measure the added value of managerial integration in the perspective affecting the results of implementation of this implementation, the Balanced Score-card model with four perspectives is chosen because it is considered very close to the value-added factors of Integration Technology in the business process, the functionality contained in the integration results of processing managers and operations data transfer is a point of the supporting of reports to plan with result accurately and reliably, so that groups, communities or individuals of people who have relationships and interests with an organization or company share the added value. Associated with the role of team managers in maintenance the results of corporate application system report still do not 
have a greater impact change in providing added value in business in the company. Assessment of an Integration Technology provides added value that results from the reporting of an enterprise application in the environment. balanced scorecard added value is expected to create added value that occurs in enterprise system applications. This research to know the question of research as follows:

1. What is the value-added implementation of integration managers for integration enterprise?

2. How to measure of Integration Technology in enterprise application?

\section{RESEARCH BACKGROUND}

\subsection{MASTER DATA}

Business processes within each organization with operational data in them managed by information systems management [3]. As well as in many industrial areas at this point, users of enterprise applications are integrated between departments. the data analysed in each department that has been conducting system application activities aimed at advancing business work. The variation of industrial application usage continues to upgrade, because: data increases rapidly every day. Required to integrate Online Analytic Processors, knowledge discovery, database functions, information resources to upgrade supporting plans, information, and other business want [15; 17]. Application examples such as special middleware: middle ware data mining can be more transformed. the application of the applied enterprise system has an final result that upgrade the chances of business competition. We focus on implementing Integration Technology to focus on improving the results of information more quickly and accurately. Measurement and value added results are predicted to occur with applications in the application of this enterprise system will be input with TOWS Matrix [2]. Measuring with 4 fundamental perspectives of its achievement in industrial system applications is a continuing task for industrial companies that apply this technology to a device within a system.

\subsection{MEASUREMENT PROCESS SYSTEM}

An efficient measurement method is accomplished by following the steps, information in reference journals and interviews [1] and done with 4 perspectives balanced scorecard. As the nearest factor and also the added value matrix in TOWS [6]. For the first, Substitution reference pools Integration Technology system with balanced scorecard 4 perspective model is managed and measured to make an analysis of results from customer perspective approach, financial approach, internal business approach, and growth and learning approach, where the questionnaire results from 4 perspectives are found that there should be a given in the plan to support reengineering business and change for the management, the balanced scorecard approach makes assessments more standardized because of the sharing of views from the four sections on which the general assessment is based, then TOWS with 4 matrices [5] then it is in the matrix to know that the use of Integration Technology is now able to make changes to a better direction.

\subsection{ABOUT INTEGRATION TECHNOLOGY}

The Reengineering Business Process (BPR) is pieces of the development of the organization's business processes within the Enterprise System that using the integration technology [8]. Value edit in business systems happen so fast, so the way in which the Integration Technology implementation is related to its integration matrix replaces current users with Integration Technology [7]. And the functionality of the user becomes more effective, efficient to focus on knowledge management and information system control 
[9]. Therefore, it is necessary to understand about Application Integration in its application in the company.

Table I. Detailed Explanation of Integration Technology and Lack of Corporate Application [10]

\begin{tabular}{|l|l|l|}
\hline Integration Approach & \multicolumn{1}{|c|}{ Strength } & \multicolumn{1}{|c|}{ Weakness } \\
\hline $\begin{array}{l}\text { Process process } \\
\text { Business } \\
\text { enterprise and IM system }\end{array}$ & $\begin{array}{l}\text { Identify the speed and } \\
\text { analysis of the system } \\
\text { work and appropriate } \\
\text { adjustments to the } \\
\text { performance process }\end{array}$ & $\begin{array}{l}\text { Complex to make changes } \\
\text { in an implementation }\end{array}$ \\
\hline $\begin{array}{l}\text { User Interface } \\
\text { review any system } \\
\text { changes with regard to in } \\
\text { every business }\end{array}$ & $\begin{array}{l}\text { Easy to use with small } \\
\text { changes to existing apps }\end{array}$ & $\begin{array}{l}\text { The application becomes } \\
\text { the thing that should be in } \\
\text { line with the business, the } \\
\text { focus discussion Difficult } \\
\text { to maintain and difficult to } \\
\text { be formed on the running } \\
\text { activities }\end{array}$ \\
\hline $\begin{array}{l}\text { Application Interface } \\
\text { explains some important } \\
\text { information }\end{array}$ & $\begin{array}{l}\text { Calling } \\
\text { applications enterprise }\end{array}$ & $\begin{array}{l}\text { each unit provides } \\
\text { information for various } \\
\text { value added }\end{array}$ \\
\hline
\end{tabular}

Table II. Stakeholders systems, The Concerns, The Influences, and Need Resources [11]

\begin{tabular}{|c|c|c|c|c|}
\hline $\begin{array}{l}\text { Stakeh } \\
\text { older }\end{array}$ & The Concerns & The Influences & Metrics & $\begin{array}{c}\text { Need } \\
\text { Resources }\end{array}$ \\
\hline $\begin{array}{l}\text { Project } \\
\text { Leader }\end{array}$ & $\begin{array}{lr}\text { Budget } & \text { and } \\
\text { Timeline for } & \text { performing } \\
\text { Concerns System }\end{array}$ & $\begin{array}{ll}\text { Input : } & \text { Systems } \\
\text { Update } & \\
\text { Output : } & \text { Funding } \\
\text { Reports } & \\
\end{array}$ & $\begin{array}{l}\text { Value } \\
\text { adding, } \\
\text { Edit } \\
\text { timeline }\end{array}$ & Finded \\
\hline $\begin{array}{l}\text { Systems } \\
\text { project } \\
\text { Enginee } \\
\mathrm{r}\end{array}$ & $\begin{array}{l}\text { Performance, } \\
\text { behaviors, } \\
\text { operability, } \\
\text { physical, } \\
\text { electrical } \\
\text { restrictions, and } \\
\text { functionality of } \\
\text { integrated } \\
\text { Systems }\end{array}$ & $\begin{array}{lr}\text { Input : } & \text { Project } \\
\text { Manager } & \\
\text { Output } & \\
\text { Subsystems } & \\
\text { engineering } & \\
\text { priorities } & \text { and } \\
\text { allocation } & \end{array}$ & $\begin{array}{l}\text { Requireme } \\
\text { nt } \\
\text { satisfactio } \\
\text { n, } \\
\text { performan } \\
\text { ce } \\
\text { parameters }\end{array}$ & $\begin{array}{l}\text { Customer use } \\
\text { cases, } \\
\text { functioning } \\
\text { Systems } \\
\text { (subsystems), } \\
\text { tested } \\
\text { interfaces }\end{array}$ \\
\hline
\end{tabular}

\subsection{MEASUREMENT OF INTEGRATION TECHNOLOGY QUALITY}

To measure the effective impact of manager integration by linking organizational business practices, such as: results, accurate information, and price, [12] then 4 perspectives in the Balanced Scorecard (BSC) is the approach factor for assessing the impact of Integration Technology as shown in Fig. 1 below this: 


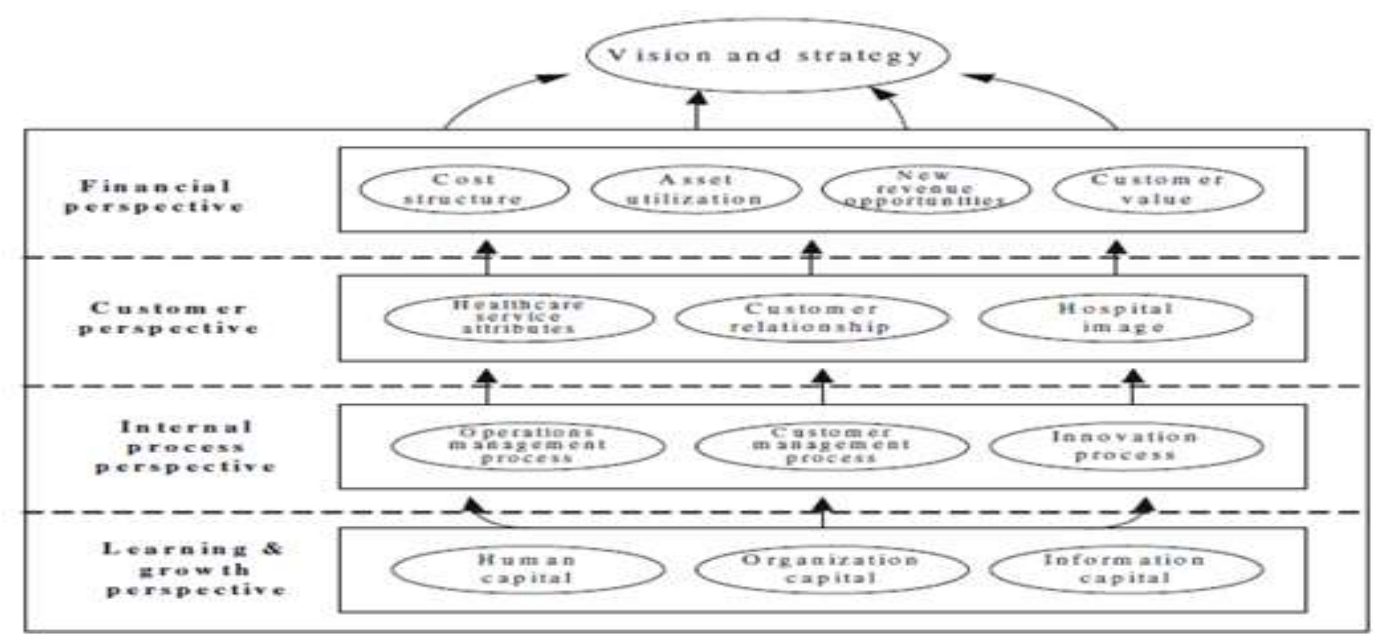

Fig. 1. The BSC Strategy Map (Adapted from Kaplan and Norton $[32,34]$ )

The results show the relevance of 4 balanced scorecard perspectives with IT investments that together show relationships linked with others improved directly from training and customer closeness. That is, the natural model, as shown in Fig. 2 is recommended.

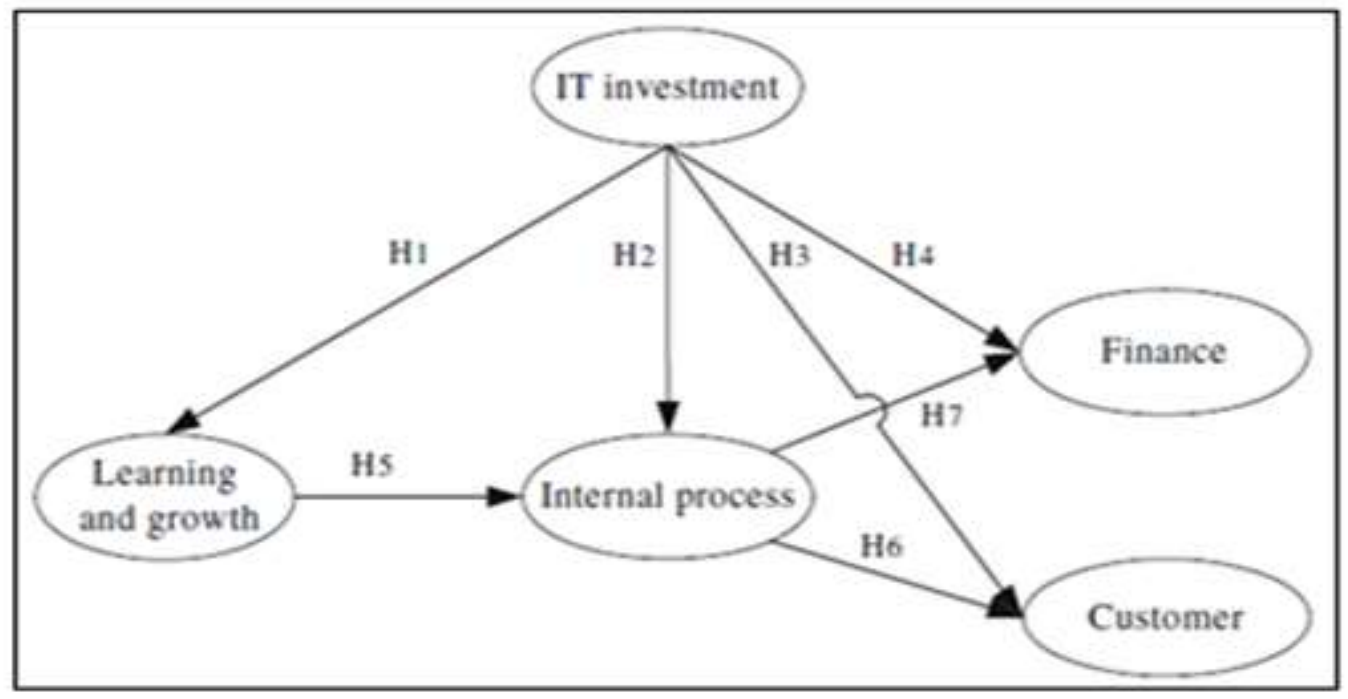

Fig. 2. Performance Framework

As a complete perspective model through the system application mediator in the company.

Level management evaluation methods are the right choice of the Balanced scorecard with several factors and value generated. This indicates there is a factor of the perpetrator and the object [13]. Balanced scorecard has the closest factor between financial and operational forms that have been useful in conducting performance reviews in the organization of business work. In the organization of industrial business work by looking at the performance of all intended users to customer satisfaction in doing business strategy. [4] The data sampling model is the model requested for validation, and refers to the company in providing questionnaires to each user responsible for using the application system. [15] 


\subsection{SUSTAINABILITY BALANCED SCORECARD}

The measurement tool is focused on the initial scale of the balanced scorecard, especially in view of the perspective of 4 important perspectives in viewing the sustainability of the Integration Technology in the company. The persistence of a performance perspective with tactical strategy and how it relates to the organizational value system. [13].

\subsection{INTEGRATION TECHNOLOGY WITH 4 PERSPECTIVE BALANCED SCORECARD}

Although a number of studies have looked at the content of the four balanced scorecard perspectives but few see from the planning strategy map, value addition is made with upgraded products and processed to offer the results back to consumers. Strategic maps appear to be valuable tools at the management level, since they simplify complex causal relationships that balanced scorecard builds with Integration Technology, so the other part of the management interest is the influence of the top or bottom level. activities in everyday business strategies and integration technologies emerge as added value that helps in the practice of departmental work. [10]

\section{DATA RESEARCH}

\subsection{COLLECTING THE DATA AND PERSPECTIVE METHOD BSC}

In a sample with Integration Technology output data in operations, where the data becomes a report in decision making and in confirmation with external parties. Then the result of the information report has been mapped into 4 balanced scorecard perspectives that have been adapted to the required columns and rows. Objects: internal and external reporting data of transactions occurring in the current period in company enterprise system applications already running at Argo Manunggal Group.

Table III. Aging receivables Report

\begin{tabular}{|c|c|c|c|c|c|c|c|c|c|c|}
\hline $\begin{array}{c}\text { Cla } \\
\text { Ss } \\
\text { ID }\end{array}$ & $\begin{array}{c}\text { Custo } \\
\text { mer } \\
\text { ID }\end{array}$ & $\begin{array}{c}\text { Custo } \\
\text { mer } \\
\text { Name }\end{array}$ & $\begin{array}{c}\text { Invoice } \\
\text { Numbe } \\
\text { r }\end{array}$ & $\begin{array}{c}\text { Due } \\
\text { Date }\end{array}$ & $\begin{array}{c}\text { Invo } \\
\text { ice } \\
\text { Amo } \\
\text { unt }\end{array}$ & $\begin{array}{c}\text { Bala } \\
\text { nce } \\
\text { Amo } \\
\text { unt }\end{array}$ & $\begin{array}{c}\mathbf{1} \text { Up } \\
\text { to 30 } \\
\text { Days }\end{array}$ & $\begin{array}{c}\mathbf{3 1} \\
\text { Up } \\
\text { to 60 } \\
\text { Days }\end{array}$ & $\begin{array}{c}\text { 61 } \\
\text { Up } \\
\text { to 90 } \\
\text { Days }\end{array}$ & $\begin{array}{c}>90 \\
\text { Days }\end{array}$ \\
\hline CI & C1 & X1 & IV1 & Date 1 & N1 & B1 & - & I1 & - & - \\
\hline CI & C2 & X2 & IV 2 & Date 2 & N2 & B2 & - & - & I2 & - \\
\hline CI & C3 & X3 & IV 3 & Date 3 & N3 & B3 & I3 & - & - & - \\
\hline CI & C4 & X4 & IV 4 & Date 4 & N4 & B4 & - & - & - & I4 \\
\hline CI & C5 & X5 & IV 5 & Date 5 & N5 & B5 & I5 & - & - & - \\
\hline
\end{tabular}

Table IV. Aging Payable Report

\begin{tabular}{|c|c|c|c|c|c|c|c|c|c|c|}
\hline $\begin{array}{c}\text { Cla } \\
\text { ss } \\
\text { ID }\end{array}$ & $\begin{array}{c}\text { Suppl } \\
\text { ier ID }\end{array}$ & $\begin{array}{c}\text { Suppl } \\
\text { ier } \\
\text { Name }\end{array}$ & $\begin{array}{c}\text { Invoice } \\
\text { Numbe } \\
\mathbf{r}\end{array}$ & $\begin{array}{c}\text { Due } \\
\text { Date }\end{array}$ & $\begin{array}{c}\text { Invo } \\
\text { ice } \\
\text { Amo } \\
\text { unt }\end{array}$ & $\begin{array}{c}\text { Bala } \\
\text { nce } \\
\text { Amo } \\
\text { unt }\end{array}$ & $\begin{array}{c}\mathbf{1} \text { Up } \\
\text { to 30 } \\
\text { Days }\end{array}$ & $\begin{array}{c}\mathbf{3 1} \\
\text { Up } \\
\text { to 60 } \\
\text { Days }\end{array}$ & $\begin{array}{c}\text { 61 } \\
\text { Up } \\
\text { to 90 } \\
\text { Days }\end{array}$ & $\begin{array}{c}>90 \\
\text { Days }\end{array}$ \\
\hline DI & S1 & Z1 & IV1 & Date 1 & N1 & B1 & I1 & - & - & - \\
\hline DI & S2 & Z2 & IV 2 & Date 2 & N2 & B2 & I2 & - & - & - \\
\hline DI & S3 & Z3 & IV 3 & Date 3 & N3 & B3 & I3 & - & - & - \\
\hline DI & S4 & Z4 & IV 4 & Date 4 & N4 & B4 & - & - & I4 & - \\
\hline DI & S5 & Z5 & IV 5 & Date 5 & N5 & B5 & I5 & - & - & - \\
\hline
\end{tabular}


Table V. Sample reporting Cash Flow Projection

\begin{tabular}{|c|c|c|c|c|c|c|c|c|c|c|c|}
\hline $\begin{array}{c}\text { CO } \\
\text { A }\end{array}$ & $\begin{array}{c}\text { Cate } \\
\text { gory }\end{array}$ & $\begin{array}{c}\text { Fore } \\
\text { cast } \\
\text { Jan } \\
\mathbf{1 8}\end{array}$ & $\begin{array}{c}\text { Fore } \\
\text { cast } \\
\text { Feb } \\
\mathbf{1 8}\end{array}$ & $\begin{array}{c}\text { Fore } \\
\text { cast } \\
\text { Mar } \\
\mathbf{1 8}\end{array}$ & $\begin{array}{c}\text { Fore } \\
\text { cast } \\
\text { Apr } \\
\mathbf{1 8}\end{array}$ & $\begin{array}{c}\text { Fore } \\
\text { cast } \\
\text { Mei } \\
\mathbf{1 8}\end{array}$ & $\begin{array}{c}\text { Fore } \\
\text { cast } \\
\text { Jun } \\
\mathbf{1 8}\end{array}$ & $\begin{array}{c}\text { Fore } \\
\text { cast } \\
\text { Jul } \\
\mathbf{1 8}\end{array}$ & $\begin{array}{c}\text { Forec } \\
\text { ast } \\
\text { Augus } \\
\text { t 18 }\end{array}$ & $\begin{array}{c}\text { Fore } \\
\text { cast } \\
\text { Sep } \\
\mathbf{1 8}\end{array}$ & $\begin{array}{c}\text { Fore } \\
\text { cast } \\
\text { Oct } \\
\mathbf{1 8}\end{array}$ \\
\hline $\mathbf{0}$ & $\begin{array}{c}\text { Beg. } \\
\text { bala } \\
\text { nce }\end{array}$ & $\mathbf{B S 1}$ & $\mathbf{B S 2}$ & $\mathbf{B S 3}$ & $\mathbf{B S 4}$ & $\mathbf{B S 5}$ & $\mathbf{B S 6}$ & $\mathbf{B S 7}$ & $\mathbf{B S 8}$ & BS9 & $\begin{array}{c}\text { BS1 } \\
\mathbf{0}\end{array}$ \\
\hline 1 & C1 & L1 & L2 & L3 & L4 & L5 & L6 & L7 & L8 & L9 & L10 \\
\hline 2 & C2 & L1 & L2 & L3 & L4 & L5 & L6 & L7 & L8 & L9 & L10 \\
\hline 3 & C3 & L1 & L2 & L3 & L4 & L5 & L6 & L7 & L8 & L9 & L10 \\
\hline 4 & C4 & L1 & L2 & L3 & L4 & L5 & L6 & L7 & L8 & L9 & L10 \\
\hline 5 & C5 & L1 & L2 & L3 & L4 & L5 & L6 & L7 & L8 & L9 & L10 \\
\hline
\end{tabular}

\section{CURRENT INTEGRATION TECHNOLOGY SYSTEMS}

In the use of Integration Technology in an enterprise provides many operational processes that serve as an accurate report, in this case is symbolized in reading the transaction data in the template and made a decision. The achievement of the enterprise system by implementing the current Integration Technology with the development of solutions and actions taken is expected to be applied to the development of enterprise systems in Argo group organization by looking at the state of the SWOT analysis that is now described below:

1 Internal Strength:

A. Sales, purchases, and stock information is always acc rate and up to date.

B. Infrastructure in IT update has been fulfilled

C. Data security maintained and held by the IT department

D. Good communication between departments with each other.

E. Have good relationships with customers and suppliers

\section{Internal Weakness}

A. Lack of production control planning with changes in information occurring

B. Archived data so stacked because there are several systems running.

C. Lack of SOP to customers.

D. The process of revising old data and difficult procedure

E. Reliance with consultants is very high.

\section{External Opportunities}

A. Produce an increasing number of orders in the textile field.

B. Establishment of production planning system with supporting application

C. Implement Supply Change Management (SCM) and Customer Relationship Management (CRM).

D. Strategy of Doing Business with ERP system.

\section{External Threats}

A. Lack of IT Internal support departments

B. Decrease in orders for orders that are late in delivery

C. Tangerang Regional minimum wage increase and flat performance.

Based on the above analysis it can be concluded that the actions taken in the Integration Technology issued a report in accordance with the SWOT analysis approach so that there will be a need to evolve as a function of the ERP system in AMG. 


\subsection{INTEGRATION TECHNOLOGY WITH 4 PERSPECTIVE BSC}

The result of Integration Technology reports related to the 4 approaches of balance scorecard perspective which through application of enterprise systems has applied relationship matrix with balance scorecard approach shown in Table 6,

Table VI. Reporting Integration Technology with 4 Perspective BSC

\begin{tabular}{|c|c|c|c|c|}
\hline $\begin{array}{c}\text { Integration Technology } \\
\text { Report }\end{array}$ & \multicolumn{4}{|c|}{ Perspective } \\
\cline { 2 - 5 } & Customer & Financial & $\begin{array}{c}\text { Business } \\
\text { Processes }\end{array}$ & Learning \\
\hline Sales Reports & 1 & 1 & 1 & 0 \\
\hline AR Aging & 1 & 1 & 1 & 0 \\
\hline Purchase Reports & 1 & 1 & 0 & 0 \\
\hline AP Aging & 1 & 1 & 0 & 0 \\
\hline Total & 4 & 4 & 2 & 0 \\
\hline
\end{tabular}

\section{INFORMATION CUSTOMER PERSPECTIVE}

The Integration Technology in the resulting report approaches the customer perspective approach, looking at the integrated data in the form of operational data for the needs of the customers and suppliers, then some reports that help the internal department to use as a confirmation reference with external parties and can be maximized as an accurate information center. Some perspectives can be included in the integration of Integration Technology; thus the way systems Integration Technology work is expected to assist in providing accurate information to avoid miss communication.

\subsection{DATA INFORMATION CUSTOMER PERSPECTIVE}

With the integration of managers strongly related to the perspective of customers then the result of added value needed by the customer will be more support in closer relationship with the customer, in this case the customer trust to be awake and good. described in the row and column below:

Table VII. Customer Information Needs with Integration Technology

\begin{tabular}{|c|c|c|c|c|}
\hline \multirow{2}{*}{$\begin{array}{c}\text { Customer } \\
\text { Perspective }\end{array}$} & \multicolumn{4}{|c|}{ Scale } \\
\cline { 2 - 5 } & $\begin{array}{c}\text { Very } \\
\text { satisfied }\end{array}$ & Satisfied & $\begin{array}{c}\text { Less } \\
\text { Satisfied }\end{array}$ & $\begin{array}{c}\text { Very Less } \\
\text { Satisfied }\end{array}$ \\
\hline Data & 8 & 2 & 0 & 0 \\
\hline accurate Information & 9 & 1 & 0 & 0 \\
\hline Finishing Report & 7 & 3 & 0 & 0 \\
\hline Repeat Order & 7 & 3 & 0 & 0 \\
\hline Total & 31 & 9 & 0 & 0 \\
\hline
\end{tabular}

\section{RESULT AND DISCUSSION}

\subsection{VALUE-ADDED WITH INTEGRATION CUSTOMER PERSPECTIVE}

Based on the results of balanced scorecard measurement in the use of Integration Technology in the application system in the company, that found many positive changes, especially in the perspective of customers, financial and business processes. user's application can bridge the integration of managers with the results of reports issued in order to support the achievement of customer satisfaction, satisfaction of financial statements, and satisfaction of work in the business process of a company. key user 
Integration Technology exist in some perspective balance scorecard which is very helpful in analyzing, this result forwarded to decision making process so happened business competition in company system.

Table VIII. Value-added with Customer Viewpoint

\begin{tabular}{|c|c|c|}
\hline Measures & Problem/solving & Development / Repair \\
\hline \multicolumn{3}{|c|}{ Customer Focus } \\
\hline $\begin{array}{l}\% \\
\text { order } \\
\text { repeat } \\
\text { takes place } \\
\text { within a } \\
\text { short } \\
\text { period of } \\
\text { time }\end{array}$ & $\begin{array}{l}\text { some customer } \\
\text { activities become } \\
\text { more focused on the } \\
\text { relationship with } \\
\text { internal users, some } \\
\text { data in check and in } \\
\text { publish to know by } \\
\text { the customer with } \\
\text { internal }\end{array}$ & $\begin{array}{l}\text { Checks some customer activities become more } \\
\text { focused on the relationship with internal users, } \\
\text { Checks some data is checked and in publish to } \\
\text { the know by the customer with internal }\end{array}$ \\
\hline $\begin{array}{l}\text { \% } \\
\text { Return } \\
\text { Order }\end{array}$ & $\begin{array}{lr}\text { reduced problem in } \\
\text { orders due to } \\
\text { process in the } \\
\text { machine } & \text { or } \\
\text { misinformation } & \\
\end{array}$ & $\begin{array}{l}\text { Check the efficiency analysis of machines in } \\
\text { the process on each machine and every order }\end{array}$ \\
\hline $\begin{array}{l}\text { \% of } \\
\text { customer } \\
\text { proximity }\end{array}$ & $\begin{array}{l}\text { Increased marketing } \\
\text { planning with } \\
\text { existing customers }\end{array}$ & $\begin{array}{l}\text { Customer needs checks are more critical in } \\
\text { helping customers deliver their product sales } \\
\text { solutions }\end{array}$ \\
\hline
\end{tabular}

Table IX. Value-added of Financial Viewpoint

\begin{tabular}{|c|c|c|}
\hline Measures & Findings & Development / Repair \\
\hline \multicolumn{3}{|c|}{ Financial Focus } \\
\hline $\begin{array}{l}\% \text { of } \\
\text { administrati } \\
\text { on Cost }\end{array}$ & $\begin{array}{l}\text { reduced cost of Item } \\
\text { Non Stock (paper and } \\
\text { ink) and added to } \\
\text { strengthen customer } \\
\text { relationships }\end{array}$ & $\begin{array}{l}\text { Prepare plan with a more focused on } \\
\text { budget planning for effective payable } \\
\text { transaction }\end{array}$ \\
\hline $\begin{array}{l}\text { \% of Cash } \\
\text { Flow } \\
\text { dashboard }\end{array}$ & $\begin{array}{l}\text { The Cash Flow } \\
\text { Statement } \quad \text { Time } \\
\text { dashboard is more open } \\
\text { and fast than ever }\end{array}$ & $\begin{array}{l}\text { preparation in doing analysis and planning } \\
\text { cash flow projection (Budgeting) }\end{array}$ \\
\hline $\begin{array}{l}\% \text { of } \\
\text { financial } \\
\text { statements }\end{array}$ & $\begin{array}{l}\text { reduce the error of } \\
\text { accounting post in } \\
\text { every transaction }\end{array}$ & $\begin{array}{l}\text { check journal data and postal analysis in } \\
\text { every transaction in the system }\end{array}$ \\
\hline $\begin{array}{l}\% \quad \text { of } \\
\text { Managemen } \\
\text { t Reporter }\end{array}$ & $\begin{array}{l}\text { More routine planning } \\
\text { analysis reports in the } \\
\text { next } 10 \text { months }\end{array}$ & $\begin{array}{l}\text { Preparation of reports can be showed } \\
\text { actual, effective and efficient, and made by } \\
\text { stakeholder decisions }\end{array}$ \\
\hline
\end{tabular}


Table X. Value-added of Internal Proses Viewpoint

\begin{tabular}{|c|c|c|}
\hline Measures & Problem/Solving & Development / Repair \\
\hline \multicolumn{3}{|c|}{ Internal Proses Focus } \\
\hline $\begin{array}{l}\% \quad \text { of } \\
\text { Current } \\
\text { Documen } \\
t\end{array}$ & $\begin{array}{l}\text { The number of } \\
\text { archived data becomes } \\
\text { more and more related } \\
\text { and accurate }\end{array}$ & $\begin{array}{l}\text { preparation of activities called digital archives or } \\
\text { digital documents that operate internally to be able } \\
\text { to follow real time Integration Technology }\end{array}$ \\
\hline $\begin{array}{l}\% \quad \text { of } \\
\text { sharing } \\
\text { Knowledg } \\
e\end{array}$ & $\begin{array}{l}\text { The reality of training } \\
\text { and problem solving } \\
\text { such as Forum Group } \\
\text { discussion in solving } \\
\text { the existing problem } \\
\text { solving }\end{array}$ & $\begin{array}{l}\text { the preparation of a group discussion forum for the } \\
\text { update information and saving of any problems that } \\
\text { occur. }\end{array}$ \\
\hline $\begin{array}{l}\% \text { of } \\
\text { Internal } \\
\text { Training }\end{array}$ & $\begin{array}{l}\text { the training process } \\
\text { develops and inputs } \\
\text { more than the general } \\
\text { standard with systems } \\
\text { and procedures related } \\
\text { to the business for its } \\
\text { use. }\end{array}$ & $\begin{array}{l}\text { preparation of routine plan and next to be growing, } \\
\text { and effectiveness in system operations in the } \\
\text { implementation of this integration }\end{array}$ \\
\hline
\end{tabular}

\subsection{MEASUREMENT OF INTEGRATION TECHNOLOGY IN ENTERPRISE APPLICATION SYSTEM}

System integration technology implemented in the application system in the company able to provide improved service criteria on the 4 perspectives made the matrix on its use, the change in work patterns and results achieved by a system application company shows the Integration Technology to improve the company system with accurate data reporting results by concluding on the results of the changes in the four balanced scorecard perspectives. In the description of the data and internal transactions repeatedly the Integration Technology helps in stabilizing the data information made, especially in the three perspective balanced scorecard perspective of Customer perspective, financial perspective, internal perspective of business processes. There is one dominant point that changes the way companies work in the use of enterprise application systems, the way the input is replaced by the data upload by the Integration Technology. By example the number of improvements in 3 balanced scorecard perspectives.

Table XI. Process Likert Scale Integration Technology Systems

\begin{tabular}{|c|c|c|c|c|}
\hline \multirow{2}{*}{$\begin{array}{c}\text { Balanced Scorecard } \\
\text { Perspective }\end{array}$} & \multicolumn{4}{|c|}{ Scale } \\
\cline { 2 - 5 } & More increase & Increase & $\begin{array}{c}\text { Less } \\
\text { Increase }\end{array}$ & $\begin{array}{c}\text { Very Less } \\
\text { Increase }\end{array}$ \\
\hline Customer & 10 & 0 & 0 & 0 \\
\hline Financial & 7 & 3 & 0 & 0 \\
\hline Internal Proses & 8 & 2 & 0 & 0 \\
\hline Growth and Learning & 0 & 0 & 0 & 0 \\
\hline Total & 25 & 5 & 0 & 0 \\
\hline
\end{tabular}

\section{MORE INCREASE}

By looking at the Likert Point scale of each added value of More Increase points, because the role of system integration technology works as a technology that 
provides added value in the direction of increasing or increasing over. At this point not too prominent.

\section{INCREASE}

In the scope of the integration of managers that also functions as a result of reports enjoyed by the financial department, the dominant happening occurs due to the implementation of Integration Technology in the application system in the company so that some reports more actual and quickly reported by the financial department.

The workings resulting from the implementation of the Integration Technology tools make each business unit become more active in learning the ability of manager integration with the goal of the Integration Technology is able to provide more effective and efficient way of working so that the application of any application system capable and successful applied in a company.

Table XII. TOWS matrix Integration Technology opportunity

\begin{tabular}{|c|c|c|}
\hline & Internal Strentgh : & Internal Weakness : \\
\hline $\begin{array}{l}\text { External } \\
\text { Opportunities : }\end{array}$ & $\begin{array}{l}\frac{\mathrm{SO}}{1 .} \text { Able to upgrade } \\
\text { customer satisfaction. } \\
\text { 2. Able to reduce } \\
\text { customer complaints against } \\
\text { the finished goods } \\
\text { 3. Improved marketing } \\
\text { strategy that can be done by } \\
\text { marketing }\end{array}$ & $\begin{array}{l}\frac{\text { WO }}{1 . \text { Prepared for large application }} \\
\text { investment in mobile } \\
\text { application } \\
\text { 2. Prepared to eliminate manual } \\
\text { work } \\
\text { 3. able to switch to cloud } \\
\text { technology }\end{array}$ \\
\hline External Threats : & $\frac{S T}{1 .} \quad$ Keep the knowledge & $\begin{array}{l}\text { WT } \\
\text { 1.Doing Business Process } \\
\text { Reengenering (BPR) with } \\
\text { more short }\end{array}$ \\
\hline
\end{tabular}

Then with the results of the improvement is done further research in related companies ie enterprise application systems and perspectives that assess the increase from the previous, then from the measurement using the balanced scorecard method is able to provide an advanced matrix in TOWS Matrix so that internal business has to see the results of technology value-added measurement Integration Technology with the value of the company's existing system information.

\subsection{THE LIMITATIONS}

This case study just measures application of integration technology in the implementation of enterprise application systems, with qualitative perspective in the balanced scorecard method. Value-added of a balanced scorecard approach in the integration matrix of technology to systems business based on the Argo Manunggal Group unit with 4 perspectives that appear to be a major improvement in customer perspectives. The authors also realize that it is not to be included in the 4 perspectives thoroughly on every division, taking only on the main perspective of the balanced scorecard so the time limitations that make measurements cannot be extended in detail and with quantitative methods, so the proposed TOWS matrix still needs to be made planning control in practice. 


\section{CONCLUSION AND FUTURE RESEACRH}

More enterprise systems are implementing applications, making many changes but major improvements are found in the implementation of integration technologies that develop the capabilities of enterprise application systems. The integration of managers who help deliver positive results from a balanced scorecard perspective with the help of the TOWS matrix that deals with outlining the company's added value in implementing this integration technology, also provides some practices that can be practiced by companies to improve the way business firms work to keep them updated. Thus, we have focus for concluded that the qualitative measurement of integration technology with the balanced scorecard as a valuation component and the TOWS matrix as the added value table gained, needs to be reinvigorated by quantitative methods and the scope expanded for measurement becomes further research.

\section{ACKNOWLEDGEMENT}

This research is the result of operational activities that occur in the manufacturing industry which is engaged in the garment and textile fields, by looking directly at the field that the operational data problems are so many, then there is the writing of this measurement with the hope that this writing is completed with the appropriate time and data happens in the field, thanks to all the informants who have provided a lot of clarity so that this article can be completed with good expectations.

\section{REFERENCES}

[1] Jain, Vikas, 2008, “A framework for sustainable ERP value ProQuest, UMI Dissertations Publishing, ISBN: 9780549687320 .

[2] Heinz Weihrich, Professor of Management, 2008, The TOWS Matrix - A Tool for Situational Analysis" University of San Francisco.

[3] Barbara C. Mcnurlin, Ralph H. Sprague, Jr, 2009, "Information Systems Management In Practice", Prentice Hall; Eighth edition.

[4] Kwang Mo Yang, Young Wook Cho, Seung Hee Choi, Jae Hyun Park, Kyoung Sik Kang, 2010, "A Study on Development of Balanced Scorecard for Management Evaluation Using Multiple Attribute Decision Making" J. Software Engineering \& Applications, 3: 268- 272.

[5] Zare Zardeini Hosein, Ahmad Yousefie, \& Seyyed Mohammad Tabatabaei Mehrizi, 2014, "Evaluating and Ranking Performance by Combination Model of Balanced Scorecard and Ariadne Uncertain Estimate" journal of Asian Social Science; Vol. 10, No. 2.

[6] Justyna Patalas-Maliszewsk, 2012, Assessing the impact of ERP implementation in the small Enterprises, Foundations of Management, Vol. 4, No. 2. ISSN 2080-7279.

[7] Sherry Finney \& Martin Corbett, 2007, ERP implementation: a compilation and analysis of critical success factors, Business Process Management Journal, Vol. 13 Iss: 3, pp.329 - 347.

[8] Lin CC, Tsai WC \& Shih DH., 2008, A Study of Information Systems Reengineering as ERP Is Introduced to Businesses Adapting to the E-Business Era. In Innovative Computing Information and Control, International Conference.

[9] Mahdavian M \& Mostajeran, 2013, F. Studying key users' skills of ERP Systems through a comprehensive skill measurement model. The International Journal of Advanced Manufacturing Technology, 69(912), 1981-1999.

[10] Rainer Lueg, 2015, "Strategy maps: the essential link between the balanced scorecard and action", Journal of Business Strategy, Vol. 36 Iss 2 pp. $34-40$.

[11] Madni AM \& Sievers M., 2014, Systems integration: Key perspectives, experiences, and challenges. Systems, 17(1), 37-51.

[12] Yung-Chi Shen, Pih-Shuw Chen \& Chun-Hsien Wang, 2015, "A Study Enterprise Resource Planning (ERP) System performance measurement using the quantitative balance scorecard approach", Elsevier B.V, Computer Industry.

[13] E. G. Hansen, 2014, "Innovation Incubator and Centre for Sustainability Management (CSM), Leuphana University of $\mathrm{Lu}$ "neburg, Scharnhorststr. 1, $21335 \mathrm{Lu}$ "neburg, Germany.

[14] VT Ravi, and G Agrawal, 2009, "Integrating and optimizing transactional memory in a data mining middleware, International Conference on High Performance Computing (HiPC), 215 - 224.

[15] Erik G. Hansen \& Stefan Schaltegger, 2012, "Pursuing Sustainability with the Balanced Scorecard" Leuphana University Luneburg. 
International Journal of Control and Automation

Vol. 12, No. 1 (2019)

[16] Wijaya Santo, 2016, Enhancing Performance of an ERP Systems with a Dashboard Systems. International conference on information management and technology page 5. 